\title{
Public infrastructure investment in the time of Covid
}

\author{
Marion Terrill ${ }^{1}$
}

\section{Abstract}

Transport infrastructure investment has been used as a crude tool in response to the economic downturn resulting from the Covid-19 pandemic. More engineering construction work has been loaded into an already crowded market, with larger projects in greater numbers than ever. Even before transport infrastructure was deployed for this task, governments were failing to deal with the most pressing problems in infrastructure delivery: overly politicised project selection, a failure to learn from history and the continual reach for megaprojects as a first resort.

No one gets much traction arguing against public infrastructure. Public infrastructure is supposed to support economic growth, facilitate human connection and generate jobs.

In pandemic times, our desire is strengthened for economic recovery, human connection and job creation, so it is no surprise that our desire for public infrastructure is strengthened, too. Since early 2020, public infrastructure has been front and centre of governments' response to the Covid-19 pandemic and associated economic downturn.

But public infrastructure is complex. This article argues that infrastructure policy in Australia took a turn for the worse in response to the pandemic. In no small part, this can be attributed to preexisting weaknesses in how governments select and appraise infrastructure projects.

1 Grattan Institute; Marion.terrill@grattan.edu.au. 


\section{An off-the-shelf response to a bespoke crisis}

Before the pandemic, public infrastructure was booming in Australia. In March 2020, the value of road and rail projects being built across the country exceeded $\$ 120$ billion for the first time. $^{2}$

Not only was the amount of work at an all-time high, so was the size of projects being built. It is no longer true that only a couple of very large projects are being built at any one time; now, most of the work being done is on 'megaprojects'-projects costing $\$ 1$ billion or more. In fact, we have entered an era of mega-megaprojects, with most work being done on projects with an expected cost of more than $\$ 5$ billion.

That was before the pandemic. Now, there are calls for even more public infrastructure. The Governor of the Reserve Bank of Australia has called for Australian governments to increase public investment to create jobs through infrastructure (Lowe, 2020, p. 5). The Prime Minister has called for the states to spend more on 'good projects' (Coorey \& Cranston, 2020). The transport and infrastructure ministers of all jurisdictions say they are 'clearing the way for an infrastructure-led recovery' (TIC, 2020, p. 1).

Given that Australia was already in new territory before the pandemic, there is a big question mark over the wisdom of this path. Even the minority of projects that have been through a reasonable assessment process before the decision to build may turn out to have not been worth building at all.

\section{Cost overruns are more likely and larger when projects are bigger}

Larger projects are more likely to have cost blowouts. Not only that, but when it happens, the blowout is likely to be larger, both in dollar terms and as a proportion of the project's cost. More than one-third of transport overruns since 2001 came from just seven of the largest projects. And there are more and more large projects: 10 years ago, the work in hand included four projects valued at $\$ 2$ billion or more in today's dollars; by the start of 2020, this number had increased to 14 (Terrill et al., 2020, p. 6).

2 Includes all projects costing more than $\$ 20$ million. 
Even before the pandemic, there was disquiet about the scale of the public infrastructure being built. In 2019, Infrastructure Australia warned that 'while large-scale projects are becoming commonplace, they are also stretching the capacity of industry and government' (Infrastructure Australia, 2019, p. 208). ${ }^{3}$

It is not hard to see cause for the disquiet. The average size of completed transport projects had been relatively steady over recent years- until 2019. The average value of projects completed in 2019 was twice that of projects completed over the previous five years (Terrill et al., 2020, p. 5). And some of these very large projects ended up in high-profile disputes between the contractor and the government-notably, Sydney's CBD and South East Light Rail and Melbourne's West Gate Tunnel.

\section{The infrastructure surge is risky}

Despite this, one of the many responses to the pandemic has been the call for more infrastructure as stimulus (Kehoe, 2020; Wright \& Crowe, 2020; Albanese, 2020), and the federal government has responded to these calls. In its 2020 and 2021 budgets, it stepped up funding for transport to about 0.6 per cent of GDP (Frydenberg \& Cormann, 2020a, pp. 6-37). This is about 1.5 times the usual level of funding from the Commonwealth. The budget included $\$ 750$ million for Queensland's Coomera Connector Stage 1 and about $\$ 600$ million each for upgrades to the New England and Newell highways in New South Wales (Frydenberg \& Cormann, 2020b, pp. 131-32).

Will this uptick in funding be an effective form of stimulus? There are three reasons for scepticism.

First, it is not a foregone conclusion that a public infrastructure project will be effective as stimulus. As leading fiscal policy expert Valerie Ramey puts it, 'details really matter' (Smith, 2020). In a comprehensive review of fiscal responses since the Global Financial Crisis (GFC), she concludes that government infrastructure projects are not the best form of stimulus because they take a long time to get going (Ramey, 2019).

A second reason for scepticism is the capacity of the construction industry. Even before the pandemic, governments were worried about the industry's capacity to take on more work on top of the record quantity of work in general and megaprojects that were under construction.

3 The Prime Minister and Treasurer also raised concerns during 2019 about capacity constraints (Coorey, 2019; Caisley, 2019). The Prime Minister said: 'We are really starting to hit our head on the ceiling in terms of how much infrastructure work you can get under way at any one time. And that's actually putting some cost pressures into the system' (Coorey, 2019). The Treasurer noted there were 'capacity constraints ... related to skills, to materials, whether that be bitumen, cement, diesel, our boring equipment, and the like' (Caisley, 2019). In March 2020, the Council of Australian Governments decided it needed to start monitoring infrastructure market conditions and capacity (COAG, 2020). 
The number of people working in engineering construction surged by 50 per cent in the three years before the pandemic. The image people may have of construction work as unskilled is out of date; as leading urban economist Ed Glaeser puts it, 'big infrastructure requires fancy equipment and skilled engineers, who aren't likely to be unemployed' (Glaeser, 2016). During the mining boom, skilled labour and machinery were imported, but with national borders closed, this option is not available now or for the foreseeable future. And during the pandemic, hours worked declined less in construction than in other industries (Productivity Commission, 2021, p. 48).

A third reason for scepticism about transport infrastructure as stimulus is that even before the pandemic, governments were already struggling to spend their budget allocations. Commonwealth allocations to the states for transport infrastructure were underspent by $\$ 1.7$ billion in 2019-20 (Frydenberg \& Cormann, 2019, p. 7). The federal government attributed this underspend to Covid-19 and the Black Summer bushfires, yet it also underspent on transport infrastructure by about $\$ 2$ billion over the preceding two years (Frydenberg \& Cormann, 2018, p. 80; Morrison \& Cormann, 2017, p. 80).

\section{Projects conceived pre-pandemic are likely to suffer benefit underruns}

A benefit underrun is just as serious as a cost overrun. Either shortcoming can render a project not worth building.

Information about the benefits of a project is harder to come by than information about the costs. Business cases often contain very little information about the expected traffic volumes underlying the benefits counted in a road project. Expected traffic volumes for toll roads have occasionally come to light after the road is completed, often as part of a court hearing that has arisen through patronage being much lower than expected (Black, 2014). ${ }^{4}$

For rail projects, it can be even harder to assess the benefits. Tasked with assessing benefits from the Regional Rail Link Project, the Victorian Auditor-General's Office noted: 'Poor benefit management practices by DOT [the Department of Transport] made it very challenging, if not impossible, to measure today whether the project has delivered all its expected benefits, and thus the level of value for money achieved' (VAGO, 2018).

\footnotetext{
4 This article relies on newspaper reports for data on expected and actual traffic volumes of road projects, because no relevant official publications have been made public.
} 
The data on benefits are scanty, but benefits should still be borne in mind when considering the merits of infrastructure proposals. The problem with projects conceived before the pandemic is that they are likely to underachieve their benefits, for two reasons.

\section{Population growth has fallen off a cliff}

Population growth underpins the business cases of most if not all the transport infrastructure projects to which governments have committed. But the Covid crisis has caused population growth to fall off a cliff. Net overseas migration fell from 239,600 in 2018-19 to $-97,000$ in 2020-21 (ABS, 2020; Frydenberg \& Birmingham, 2021a, p. 45). We should not assume a return to the high-immigration policies Australia had for many years before Covid.

Natural increase is well down, too. Australia's fertility rate, of 1.69 babies per woman (Frydenberg \& Cormann, 2020a, pp. 2-34), is expected to fall to 1.62 by early next decade (McDonald, 2020, pp. 2-4). The federal government expects the rate of population growth to be permanently lower than the rates assumed before Covid-19 (Frydenberg \& Cormann, 2020a, pp. 2-34).

Of course, infrastructure is a long-term investment and Infrastructure Australia is continuing to take a 30-year view of projects, even amid Covid-19. But we do not yet know whether Australia will resume its old path in a couple of years.

\section{Work and travel patterns are likely to be different post pandemic}

Before the pandemic, few Australians worked from home. In Sydney, Melbourne and Brisbane, about 5 per cent did, and in Perth and Adelaide it was about 4 per cent (Terrill et al., 2018, Ch. 4). The numbers were small, but the trend was up: the rate of working from home increased by about 0.5 percentage point between 2011 and 2016 in each of Australia's five largest cities (Terrill et al., 2018, Ch. 4).

That changed, of course, with the pandemic. People who could work from home did so; an estimated 40 per cent of jobs can be done from home in Australia (Ulubasoglu \& Onder, 2020). Some people love the flexibility and comfort of working at home and enjoy making use of the time that used to be swallowed up with commuting. Others miss the social side of work and find it difficult to work while their children are at home. Some businesses look forward to saving on office rental costs; others are concerned about doing new business in a world where people don't often meet face to face. Future work patterns and preferences are unclear. ${ }^{5}$

5 Beck et al. (2020) found that 71 per cent of people who had worked from home during the pandemic said they would like to work from home more often in the future; but how frequently people will work from home after the pandemic remains uncertain. 
Likewise, future demand for public transport is unclear. No one knows how effective the Covid-19 vaccines may be against future variants of the virus, nor what kinds of social distancing may be required in the long term. If social distancing is sustained, public transport projects—-premised on the idea of carrying large numbers of people in close proximity—will need to be rethought.

In a time of high uncertainty, the best strategy is to keep options open. Major commitments to new transport infrastructure conceived for very different times make little sense right now. The mantra of stimulus does not mean every project is a good one.

In all, infrastructure-particularly large infrastructure-is simply not well suited to leading recovery from the downturn induced by the emergence of Covid-19 in Australia.

\section{Public infrastructure is rife with preexisting problems}

Governments across the country have expressed a willingness and desire to improve infrastructure decision-making, with infrastructure advisory bodies now established in all states and at the Commonwealth level. ${ }^{6}$ All have different functions and varying degrees of independence, but most focus on project assessment and longterm strategy. The creation of these bodies, between 2011 and 2019, is a positive step, but a modest one. Three key shortcomings are politicised project selection, a failure to learn from history and the continual reach for megaprojects.

\section{Politicised project selection}

Project selection is not straightforwardly technical; ministers are empowered and expected to determine priorities for infrastructure investment, but they are expected to do so prudently, with care and regard for public resources and the needs of the whole community.

Yet governments and oppositions tend to go into elections promising infrastructure projects without knowing whether they are the best solution to a problem, let alone whether the scope, cost and timing they are promising are realistic. At the 2018 Victorian election, only 17 per cent of the Australian Labor Party's promised infrastructure investment was for projects with an assessed business case and benefits in excess of costs; the Coalition was little better at 23 per cent, and the Greens, zero (Terrill \& Ha, 2018). At the 2019 NSW election, the story was similar: only

6 Examples include Infrastructure NSW and Infrastructure Victoria. 
19 per cent of the Coalition's promised spend was on projects with a business case assessed by an independent infrastructure body; for Labor, it was 23 per cent (Terrill \& Ha, 2019).

In theory, it is possible for a government to reassess the projects it has announced and abandon those that, on closer scrutiny, are not worth building. But this rarely happens; more than 80 per cent of transport projects with an initial cost estimate of at least $\$ 20$ million announced since 2001 were seen through to completion (Terrill et al., 2020, p. 19).

The problem is not limited to announcements made in the lead-up to elections. Of 32 projects larger than $\$ 500$ million committed to since 2016 , only eight had a business case either published or assessed by a relevant infrastructure body at the time of commitment (Terrill et al., 2020, pp. 29-31).

And governance has been no better for those projects that have received Commonwealth Government support. Of 22 large projects to which the Commonwealth committed a contribution since 2016, only six had a business case published or assessed by Infrastructure Australia. A further 14 were listed as 'initiatives' on Infrastructure Australia's priority list, indicating that they 'have the potential to address a nationally significant problem or opportunity' but their assessment had not been completed. The remaining two had not appeared on any Infrastructure Australia priority list at the time a state government committed to them (Terrill et al., 2020, pp. 29-31).

When a project is announced early, before it is adequately understood, this usually means its cost estimate is a preliminary one and does not incorporate a detailed engineering design or feasibility assessment. Premature announcements are not the norm; they occur about one-third of the time. ${ }^{7}$ However, they have been responsible for more than three-quarters of the value of cost overruns accrued on public road and rail projects over the past two decades (Terrill et al., 2020, p. 19).

Unrealistic cost estimates distort investment planning in three ways. First, if governments systematically underestimate costs, the benefit-cost ratios will be systematically overstated; this leads governments to overinvest in transport infrastructure. Second, if governments misunderstand the uncertainty in a project's cost at the time they commit, their decision to invest in that project is made on an incorrect basis. This distorts the decision to invest and the selection of projects. Third, because unrealistic cost estimates are more prevalent for large projects-as evidenced by the greater prevalence of cost overruns on larger projects—governments are more likely to overinvest in these projects.

7 An announcement is defined as premature when a government or opposition announces it will build a project for a particular cost, but the project does not yet have the regulatory and/or financial approvals that constitute a technical commitment, and which are needed before it can proceed. 
As well as distorting investment decisions, unrealistic cost estimates mislead the public. We are led to believe that a particular project is available to us for less than it really is.

\section{Failure to learn from history}

There is an element of chance in any individual project finishing on budget. It would therefore be fair to argue that imperfect cost estimates simply reflect the difficulty of the cost estimation task-if it were also true that cost underruns were anywhere near as common or as large as cost overruns.

But overruns are much more common and much larger than underruns (Terrill et al., 2020 , p. 14). The reasons are not a mystery: large projects are more prone to overruns and to larger overruns, and prematurely announced projects are more prone to overruns, which are often larger, too. Even after contracts are signed, it is common for governments to spend more than they claimed they would (Terrill et al., 2021, pp. 8-9).

Governments do not collect the data that would permit better cost estimation. Despite calls from road experts from all jurisdictions, the Department of Infrastructure, Regional Development and Cities, the Productivity Commission and even the Transport and Infrastructure Council of the Council of Australian Governments, there is very little progress towards collating the data from past projects to form a benchmarking series (Terrill et al., 2020, pp. 37-38).

One clear manifestation of the scarcity of data is that cost estimates of current projects continue to make insufficient provision for 'worst-case' outcomes.

Business cases typically include an estimate of the median cost, or 'P50', and the worst case, or 'P90'. In business cases produced in recent years, the difference between P50 and P90 cost estimates is generally about 7 per cent. But the experience of the past two decades has shown that the real difference between the P50 and P90 costs is 49 per cent, on average, as detailed in Table 1.

8 'P50' refers to the amount the actual project cost will exceed the estimate in 50 per cent of cases. 'P90' refers to the amount the actual project cost will exceed the estimate in the worst 10 per cent of cases. 
Table 1. The difference between median and 'worst-case' cost forecasts is much lower, on average, than experienced

\begin{tabular}{|c|c|c|c|c|}
\hline \multirow[b]{2}{*}{ Project } & \multirow[b]{2}{*}{ State } & \multicolumn{2}{|c|}{ Cost forecast (nominal, $\$ \mathrm{~m}$ ) } & \multirow[b]{2}{*}{$\begin{array}{l}\text { Difference } \\
\text { between median } \\
\text { and 'worst-case' } \\
\text { cost forecasts (\%) }\end{array}$} \\
\hline & & Median & 'Worst case' & \\
\hline Inland Rail & National & 9,889 & 10,657 & 7.8 \\
\hline Metro Tunnel & Vic. & 10,154 & 10,837 & 6.7 \\
\hline West Gate Tunnel & Vic. & 5,226 & 5,548 & 6.2 \\
\hline Canberra Light Rail & ACT & 759 & 806 & 6.2 \\
\hline $\begin{array}{l}\text { Bruce Highway - Cairns Southern } \\
\text { Access Corridor (Stage 3) }\end{array}$ & Qld & 470 & 500 & 6.4 \\
\hline $\begin{array}{l}\text { Bruce Highway - Cairns Southern } \\
\text { Access Corridor (Stage 4) }\end{array}$ & Qld & 97 & 104 & 7.2 \\
\hline $\begin{array}{l}\text { M1 Pacific Motorway_Eight Mile } \\
\text { Plains to Daisy Hill }\end{array}$ & Qld & 713 & 747 & 4.8 \\
\hline $\begin{array}{l}\text { M1 Pacific Motorway - Varsity } \\
\text { Lakes to Tugun }\end{array}$ & Qld & 960 & 1,017 & 5.9 \\
\hline \multirow{3}{*}{$\begin{array}{l}\text { Townsville Eastern Access Rail } \\
\text { Corridor }\end{array}$} & Qld & 369 & 392 & 6.2 \\
\hline & & \multicolumn{2}{|c|}{ Benefit/cost ratio } & \\
\hline & & Median & 'Worst case' & Difference (\%) \\
\hline $\begin{array}{l}\text { Beerburrum to Nambour Rail } \\
\text { Upgrade }\end{array}$ & Qld & 1.48 & 1.35 & 9.6 \\
\hline $\begin{array}{l}\text { Bruce Highway-Deception Bay } \\
\text { Road Interchange }\end{array}$ & Qld & 3.23 & 3.03 & 6.6 \\
\hline $\begin{array}{l}\text { Bruce Highway - Maroochydore } \\
\text { Interchange }\end{array}$ & Qld & 3.4 & 3.2 & 6.0 \\
\hline $\begin{array}{l}\text { Bruce Highway-Bribie Island } \\
\text { to Steve Irwin Way }\end{array}$ & Qld & 2.02 & 1.91 & 5.8 \\
\hline Centenary Bridge Upgrade & Qld & 0.85 & 0.75 & 13 \\
\hline $\begin{array}{l}\text { Smithfield Transport Corridor } \\
\text { Upgrade }\end{array}$ & Qld & 2.9 & 2.6 & 11 \\
\hline $\begin{array}{l}\text { Average difference of above } \\
\text { estimates }\end{array}$ & & & & $7.3 \%$ \\
\hline $\begin{array}{l}\text { Average of the actual difference fror } \\
\text { completed between } 2001 \text { and } 2020\end{array}$ & $\begin{array}{l}m \text { the mec } \\
0\end{array}$ & an cost forecas & , all projects & $49 \%$ \\
\hline
\end{tabular}

For details and sources, see Terrill et al. (2020, p. 40). 
This comparison of cost estimation practice and actual experience shows that either median cost estimates are generally too high or-more likely-'worst-case' cost estimates are generally too low. ${ }^{9}$ Cost estimators are making insufficient provision for fairly unlikely events that cause large overruns.

For example, the P90 forecast for Melbourne's West Gate Tunnel project in the 2015 business case was $\$ 5.548$ billion-6.2 per cent higher than the P50 forecast. Were this P90 forecast valid, it would indicate there is only a 10 per cent probability that the eventual project cost will exceed $\$ 5.548$ billion. However, the current cost estimate is already $\$ 6.7$ billion, and there are reports that costs could further blow out (Jacks \& Towell, 2020). Given this situation, it seems unlikely that the P90 forecast of $\$ 5.548$ billion took sufficient account of adverse contingencies.

\section{Overreliance on megaprojects}

Projects worth $\$ 1$ billion were a rarity two decades ago. In 2001 , there were just two such projects under construction; by 2020, there were 18 .

Megaprojects have become more prevalent at the same time as there has been a push to greater national integration and more active Commonwealth involvement in transport infrastructure. Bodies such as the Australian Rail Track Corporation, the National Transport Commission and Infrastructure Australia have been created to deal with this greater focus on national planning and coordination.

The Commonwealth has not restricted itself to planning and coordination, however. Every federal budget and every federal election include announcements of big, iconic, 'nation-building' infrastructure.

Megaprojects have become normal. They have often been justified on the grounds of strong population growth. What is less often stated but just as important are exceptionally low real interest rates since the GFC, which have resulted in very strong land price increases. Land acquisition has become more important because planning authorities no longer assume large cities will keep expanding outwards, and tunnelling has become common.

Governments have choices about how to respond to these pressures.

The first resort should be efficient usage of the infrastructure we already have. Where there is excessive road congestion in peak periods, the most efficient remedy is congestion pricing. Public transport fares should be higher during peak periods.

9 In fact, relying on median cost estimates will systematically understate the cost of the portfolio of projects. This is because the distribution of cost estimates is right-skewed and therefore the mean, or expected value, is greater than the median cost estimate. 
Efficient use of existing infrastructure requires dealing with the mounting maintenance backlog. A historical underspend on preventative maintenance, a lack of data and inadequate reporting requirements have contributed to a maintenance backlog across all infrastructure sectors. This will erode the quality and reliability of many assets and cause higher costs for future asset maintenance and renewal (Infrastructure Australia, 2019, p. 50).

There is also scope to modestly upgrade existing infrastructure, such as widening or upgrading key arterial roads, improving surfaces, upgrading railway stations and improving key road intersections. For instance, if dilapidated wooden bridges were replaced with steel bridges, they would be able to handle B-double semitrailers, which must currently take circuitous routes instead.

Smaller projects generally have higher benefit-cost ratios (Infrastructure Australia, 2019, p. 298). They are more robust to a range of future scenarios, such as the fall in population growth caused by the pandemic response. Keeping options open, particularly in a time of high uncertainty, is a smart strategy.

It is a long way from these infrastructure projects to the $\$ 1$ billion-plus megaprojects, let alone the $\$ 5$ billion-plus mega-megaprojects. Rather than reaching for the heroic and iconic megaproject, governments should focus on upgrading and improving existing infrastructure.

\section{Conclusion}

Transport infrastructure is undoubtedly popular electorally, and political parties select their transport projects to express their ethos and their geographic priorities. Present expenditure on transport infrastructure is high by historical standards (BITRE, 2020, pp. 52, 68), at the same time as federal and state budgets are seriously dented by the response to the Covid-19 pandemic.

The opportunity is clear: toning down the overly political project selection, investing in learning the lessons of past projects and reaching for smaller, higher-benefit projects are the key ingredients to boost the productive capacity of the transport system.

If governments choose this path, a pandemic-constrained budget could have a genuine silver lining. 


\section{References}

Albanese, A. (2020). Australia beyond the coronavirus. Fifth Vision Statement speech, Canberra, 10 May. Available from: www.youtube.com/watch?v=Ow1PdcfeL2E.

Australian Bureau of Statistics (ABS). (2020). Migration, Australia, 2018-19 financial year (Cat. No. 3412.0). Australian Bureau of Statistics. Available from: www.abs.gov.au/ statistics/people/population/migration-australia/2018-19.

Beck, M.J., Hensher, D.A. \& Wei, E. (2020). Slowly coming out of Covid-19 restrictions in Australia: Implications for working from home and commuting trips by car and public transport. Journal of Transport Geography, 88, 102846. doi.org/10.1016/j.jtrangeo.2020. 102846.

Black, J. (2014). Traffic risk in the Australian toll road sector. Public Infrastructure Bulletin, 1(9), 18-29. Available from: www.semanticscholar.org/paper/Traffic-risk-in-the-Australian-tollroad-sector-Black/80142c0791dd6ff67f7cc2f3c1ec7580d8c34894.

Bureau of Infrastructure and Transport Research Economics (BITRE). (2020). Yearbook 2020: Australian infrastructure statistics (Statistical Report). Department of Infrastructure, Transport, Regional Development and Communications. Available from: www.bitre. gov.au/sites/default/files/documents/bitre_aus_infrastructure_yearbook_2020.pdf.

Caisley, O. (2019). Frydenberg vows to tackle capacity constraints hampering infrastructure projects. The Australian, 11 October. Available from: www.theaustralian.com.au/nation/ josh-frydenberg-rejects-state-push-to-bring-back-asset-recycling/news-story/2147b64f5 c81d6062d87450bec7acb98.

Coorey, P. (2019). Infrastructure boom triggers cost blowouts: PM. Australian Financial Review, 5 September. Available from: www.afr.com/politics/federal/infrastructure-boomtriggers-cost-blowouts-pm-20190904-p52o18.

Coorey, P. \& Cranston, M. (2020). Spend big but don't make whoopee, PM tells states. Australian Financial Review, 14 August. Available from: www.afr.com/politics/federal/ spend-big-but-don-t-make-whoopee-pm-tells-states-20200814-p55lnz.

Council of Australian Governments (COAG). (2020). Communiqué of the meeting of 13 March 2020. Council of Australian Governments. Available from: www.coag.gov.au/ sites/default/files/communique/communique-13-march2020.pdf.

Frydenberg, J. \& Birmingham, S. (2021a). Budget 2021-22: Budget strategy and outlook (Budget Paper No. 1, 2021-22). Australian Government. Available from: budget.gov.au/ 2021-22/content/bp1/download/bp1_2021-22.pdf.

Frydenberg, J. \& Birmingham, S. (2021b). Budget 2021-22: Budget measures (Budget Paper No. 2, 2021-22). Australian Government. Available from: budget.gov.au/2021-22/ content/bp2/download/bp2_2021-22.pdf. 
Frydenberg, J. \& Cormann, M. (2018). Final budget outcome, 2017-18. Australian Government. Available from: archive.budget.gov.au/2017-18/fbo/FBO_2017-18_ Combined.pdf.

Frydenberg, J. \& Cormann, M. (2019). Final budget outcome, 2018-19. Australian Government. Available from: archive.budget.gov.au/2018-19/fbo/FBO_2018-19_web. pdf.

Frydenberg, J. \& Cormann, M. (2020a). Budget 2020-21: Budget strategy and outlook (Budget Paper No. 1, 2020-21). Australian Government. Available from: archive. budget.gov.au/2020-21/bp1/download/bp1_w.pdf.

Frydenberg, J. \& Cormann, M. (2020b). Budget 2020-21: Budget measures (Budget Paper No. 2, 2020-21). Australian Government. Available from: archive.budget.gov.au/202021/bp2/download/bp2_complete.pdf.

Glaeser, E.L. (2016). If you build it ...: Myths and realities about America's infrastructure spending. City Journal, (Summer). Available from: www.city-journal.org/html/if-youbuild-it-14606.html.

Infrastructure Australia. (2019). The Australian Infrastructure Audit 2019: An assessment of Australia's future infrastructure needs. 13 August. Australian Government. Available from: www.infrastructureaustralia.gov.au/publications/australian-infrastructure-audit-2019.

Jacks, T. \& Towell, N. (2020). Deal cut on Metro Tunnel's blowout billions after government 'cave in'. The Age, [Melbourne], 15 October. Available from: www.theage.com.au/ national/victoria/deal-cut-on-metro-tunnel-s-blowout-billions-after-government-cavein-20201015-p565a5.html.

Kehoe, J. (2020). Why the RBA boss wants the stimulus to shift. Australian Financial Review, 24 August. Available from: www.afr.com/policy/economy/rba-boss-urges-stimulus-shift20200813-p55lbi.

Lowe, P. (2020). Reserve Bank of Australia annual report 2019 (Official Committee Hansard, 14 August). House of Representatives Standing Committee on Economics. Available from: parlinfo.aph.gov.au/parlInfo/download/committees/commrep/868db039-23844ce9-a502-1354709677d2/toc_pdf/Standing\%20Committee\%20on\%20Economics_ 2020_08_14_7974_Official.pdf;fileType=application $\% 2$ Fpdf\#search $=\% 22$ committees $/$ commrep/868db039-2384-4ce9-a502-1354709677d2/0000\%22.

McDonald, P. (2020). A projection of Australia's future fertility rates (Centre for Population Research Paper, September). Australian Government. Available from: population.gov.au/ downloads/McDonaldFertilityProjections.pdf.

Morrison, S. \& Cormann, M. (2017). Budget 2017-18: Budget strategy and outlook (Budget Paper No. 1, 2017-18). Australian Government. Available from: archive.budget.gov. au/2017-18/bp1/bp1.pdf. 
Productivity Commission. (2021). Things you can't drop on your feet: An overview of Australia's services sector productivity (PC Productivity Insights, April). Australian Government. Available from: www.pc.gov.au/research/ongoing/productivity-insights/ services/productivity-insights-2021-services.pdf.

Ramey, V.A. (2019). Ten years after the financial crisis: What have we learned from the renaissance in fiscal research? Journal of Economic Perspectives, 33(2), 89-114. doi.org/ 10.1257/jep.33.2.89.

Smith, T. (2020). Supplying a fiscal lifeline: Valerie Ramey discusses what economists have learned about stimulus since the 2008 financial crisis (Research Highlights, 13 May). American Economic Association. Available from: www.aeaweb.org/research/valerie-ramey-fiscalpolicy-after-financial-crisis.

Terrill, M., Batrouney, H., Ha, J. \& Hourani, D. (2018). Remarkably adaptive: Australian cities in a time of growth (Grattan Institute Report No. 2018-13, November). Grattan Institute. Available from: grattan.edu.au/wp-content/uploads/2018/10/909Remarkably-adaptive-Australian-cities-in-a-time-of-growth.pdf.

Terrill, M., Emslie, O. \& Fox, L. (2021). Megabangfor megabucks: Driving a harder bargain on megaprojects (Grattan Institute Report No. 2021-04, May). Grattan Institute. Available from: grattan.edu.au/wp-content/uploads/2021/05/Megabang-for-megabucks-Drivinga-harder-bargain-on-megaprojects.pdf.

Terrill, M., Emslie, O. \& Moran, G. (2020). The rise of megaprojects: Counting the costs (Grattan Institute Report No. 2020-15, November). Grattan Institute. Available from: grattan.edu. au/wp-content/uploads/2020/11/The-Rise-of-Megaprojects-Grattan-Report.pdf.

Terrill, M. \& Ha, J. (2018). Eight charts that explain Victoria's transport election. The Conversation, 21 November. Available from: grattan.edu.au/news/eight-charts-thatexplain-victorias-transport-election/.

Terrill, M. \& Ha, J. (2019). How the NSW election promises on transport stack up. The Conversation, 14 March. Available from: grattan.edu.au/news/how-the-nsw-electionpromises-on-transport-stack-up/.

Transport and Infrastructure Council (TIC). (2020). Transport and Infrastructure Council communiqué. 5 June. Department of Infrastructure, Transport, Regional Development and Communications. Available from: www.infrastructure.gov.au/sites/default/files/ migrated/transport/infrastructure-transport-ministers/files/13th-transport-andinfrastructure-council-communique.pdf.

Ulubasoglu, M. \& Onder, Y.K. (2020). Teleworkability in Australia: 41 per cent of full-time and 35 per cent of part-time jobs can be done from home. The Conversation, 29 June. Available from: theconversation.com/teleworkability-in-australia-41-of-full-time-and35-of-part-time-jobs-can-be-done-from-home-140723. 
Victorian Auditor-General's Office (VAGO). (2018). Assessing benefits from the Regional Rail Link Project (Independent assurance report to Parliament 2017-18: 18, May). Victorian Auditor-General's Office. Available from: www.audit.vic.gov.au/sites/default/files/201805/20180510-Regional-Rail-Link.pdf.

Wright, S. \& Crowe, D. (2020). A 'short-term window' to build infrastructure for long-term gain. The Age, [Melbourne], 7 September. Available from: www.theage.com.au/politics/ federal/a-short-term-window-to-build-infrastructure-for-long-term-gain-20200906p55sc5.html. 
This text is taken from Agenda, Volume 28 - Number 1, 2021 edited by William Coleman, published 2021 by ANU Press, The Australian National University, Canberra, Australia.

doi.org/10.22459/AG.28.01.2021.08 